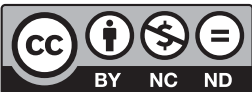

Estudos Teológicos foi licenciado com uma Licença Creative Commons Atribuição - NãoComercial - SemDerivados 3.0 Não Adaptada

http://dx.doi.org/10.22351/et.v60i1.3918

\title{
RELIGIÃo DE MATRIZ AFRO-BRASILEIRA NO PENSAMENTO SOCIAL: DO RACISMO DOUTRINÁRIO À VIOLAÇÃO DE DIREITOS ${ }^{1}$
}

\author{
Religion of afro-Brazilian matrix in social thinking: \\ from doctrinal racism to rights violation
}

\section{Sergio Luis do Nascimento ${ }^{2}$}

Resumo: Apresento, neste artigo, uma revisão sobre os estudos e as pesquisas das religiões de matriz afro-brasileira no pensamento social brasileiro e sobre estereótipos, perseguições, preconceitos em relação a essas matrizes. Aporia, em que tudo aquilo que no cotidiano da vida prática se manifesta como sendo senso comum, outrora foi senso. A extensão dessa aporia relaciona-se com a necessidade de traçar um quadro sócio-histórico aprofundado acerca das teorias raciais no Brasil e das religiões afro-brasileiras, buscando sua análise e as interseções entre os temas na descrição sobre o constructo do racismo epistemológico e a violação dos direitos humanos. O artigo utilizará as pesquisas antropológicas, históricas, jornalísticas e psicanalíticas de importantes pensadores do final do século XIX e início do $\mathrm{XX}$, que se destacaram na história do pensamento sociorracial brasileiro por estabelecerem uma linha de análise em torno dos estudos que envolvem relação racial, religiões de matriz afro-brasileira e intolerância religiosa.

Palavras-chave: Religião. Raça. Ideologia. Direitos humanos.

\begin{abstract}
This article presents a review about studies and researches on afro-Brazilian religions in Brazilian social thought and on stereotypes, persecutions, prejudices related to these matrices. Aporia, in which everything about the daily routine is shown as common sense, in the past was just a sense. The extension of this aporia is related to the need of drawing a deep socio-historical study about racial theories in Brazil and afro-Brazilian religions, aiming at its analysis and the intersections between the themes in the description of the epistemological racism construct and the violation of human rights. The article will use anthropological, historical, journalistic and psychoanalytic researches by important thinkers from the end of 19th and beginning of 20th centuries who became well known in the history of Brazilian socio-racial thinking for establishing a line of analysis around studies involving racial relations, afro-Brazilian religions and religious intolerance.
\end{abstract}

Keywords: Racism. Religion. Ideology. Human rights.

1 O artigo foi recebido em 27 de fevereiro de 2020 e aprovado em 05 de maio de 2020 com base nas avaliações dos pareceristas ad hoc.

2 Doutor em Educação. PUCPR. E-mail: axesergio42@gmail.com 


\section{Introdução}

Neste artigo serão abordadas as temáticas das religiões de matriz afro-brasileira no pensamento sociorracial brasileiro e o legado de intolerância e estereótipos aos cultos afro-brasileiros. Para isso se utilizarão as pesquisas antropológicas, históricas, jornalísticas e psicanalíticas de importantes pensadores do final do século XIX e início do XX que se destacaram na história do pensamento sociorracial brasileiro. O objetivo do artigo é estabelecer uma linha de análise em torno dos estudos que envolvem relação racial e violação de direitos junto as religiões de matriz afro-brasileira. Para essa análise, a metodologia amparou-se na análise formal ou discursiva produzida nos contextos interpretativos da Teoria da Hermenêutica de Profundidade (HP) de Thompson, bem como nos estudos contemporâneos sobre os discursos racistas. ${ }^{3}$ A partir dos cinco modos gerais de operação da ideologia, entre eles: legitimação, dissimulação, unificação, fragmentação e reificação. Cabe salientar que cada um desses modos gerais está relacionado a algumas estratégias típicas de construção simbólica ideológica. ${ }^{4}$

\section{Consolidação do estereótipo negativo das religiões de matriz afro-brasileira}

As temáticas do Ensino Religioso e das religiões de matriz afro-brasileira proporcionam ao pesquisador de políticas públicas diferentes frentes de análise. Isso porque, sobre essa temática, o pesquisador deve ficar atento às diferentes áreas de conhecimento que tratam do assunto. Entre essas áreas, é impossível não ficar atento às discussões que a antropologia realiza desde Nina Rodrigues com $O$ animismo fetichista dos negros baianos (2006). O pesquisador, que era médico legista, é sempre lembrado como fundador da antropologia brasileira ${ }^{5}$, mesmo apresentando pressupostos racialistas ${ }^{6}$ em sua obra sobre as religiões de matriz afro-brasileira. Ele é sempre lembrado pelos autores, entre eles Roger Bastide, como o cientista que "fixou os dois pontos de referência do estudo das religiões afro-brasileiras para toda a primeira metade do século XX, o psicologismo e a Etnografia"7.

3 THOMPSON, J. B. Ideologia e cultura moderna: teoria social na era dos meios de comunicação de massa. Petrópolis: Vozes, 1995.

4 THOMPSON, 1995, p. 80-89.

5 RODRIGUES, N. O animismo fetichista dos negros baianos. Rio de Janeiro: Fundação Biblioteca Nacional; UFRJ, 2006. p. 9. Original publicado em 1900.

6 Nina Rodrigues, ao longo de todo o texto, expõe de forma explícita o preconceito contra a população negra e as religiões afro-brasileiras, em passagens tais como: "a incapacidade psychica das raças inferiores para as elevadas abstracções do monotheismo"; "monotomia grave e triste da música rude e da melopéa africana, o caracter estravagante e estranho das dansas religiosas, tudo concorria ali para dar ao conjunto um cunho de poesia selvagem e mysteriosa que devia falar profundamente no espírito acanhado e inculto de uma raça supersticiosa (RODRIGUES, 2006, p. 27).

7 BASTIDE, R. As religiões africanas no Brasil: contribuições a uma sociologia das interpenetrações de civilizações. São Paulo: Universidade de São Paulo, 1960. p. 33. 
O discípulo de Nina Rodrigues e também médico legista, Arthur Ramos, é considerado um cânone do pensamento social brasileiro. Publicou, em 1934, O negro brasileiro, que utiliza a psicanálise no estudo da cultura, do ritual, dos processos de magia, dos fenômenos de possessão fetichista, do sincretismo religioso e dos mitos negros. Para ele, tais estudos "têm que ser reinterpretados com novos métodos de pesquisa científica" ${ }^{\text {" }}$ O autor identificava nesses estudos a compreensão de tramas inconscientes do logro e da superstição cujo alcance tem no presente trabalho questões de cunho higiênico e educacional. ${ }^{9}$ Esses novos métodos ajudaram também Arthur Ramos a superar as categorias de civilizações superiores e inferiores de Nina Rodrigues e possibilitou ao discípulo ampliar a discussão iniciada do seu antigo mestre, afirmando que a teoria animista já não tinha significado naquele momento histórico.

Nina Rodrigues e Arthur Ramos inauguraram, por meio da antropologia, uma linha de análise sobre a temática que se tornou referência para os estudos da antropologia brasileira em relação aos negros e às religiões de matriz afro-brasileira, a racionalização ${ }^{10}$. O jornalismo aparece em nosso estudo e antecede à análise dessas outras áreas de conhecimento no pensamento sociorracial brasileiro, pelo fato de as primeiras descrições sobre as macumbas no Rio de Janeiro não passarem de sugestivas reportagens jornalísticas de João do Rio, pseudônimo de João Paulo Emílio Cristóvão dos Santos Coelho Barreto (1906). Ele percorreu os terreiros do Rio de Janeiro à época para escrever uma série de reportagens intitulada As religiões no Rio para o jornal Gazeta. O trabalho de João do Rio ilustra uma lógica de menosprezo e desrespeito com as crenças afro-brasileiras, isso fica mais nítido quando ele descreve as iaôs ${ }^{11}$ do candomblé como prostitutas, loucas, histéricas, demoníacas. ${ }^{12}$ Cabe salientar o quanto essas ideias refletem o imaginário social já daquela época, uma vez que justamente ecoava pensamentos enraizados na mentalidade da época. Vê-se como o autor trata as iaôs:

As iaôs abundam nesta Babel da crença, cruzando-se com a gente diariamente, sorriem aos soldados ébrios nos prostíbulos baratos, mercadejam doces nas praças, às portas dos estabelecimentos comerciais, fornecem ao hospício a sua cita de loucura, propagam a histeria entre as senhoras honestas e as cocotes, exploram e são exploradas, vivem da crendice e alimentam o caftismo inconsciente. As iaôs são as demoníacas e as grandes farsistas da raça preta, as obsedadas e as delirantes. A história de cada uma delas, quando não é sinistra pantomima de álcool e manceba, é um tecido de fatos cruéis, anormais, inéditos, feitos de invisível, de sangue e de morte. Nas iaôs está a base do culto africano. Todas elas usam sinais exteriores do santo, as vestimentas simbólicas, os rosários e os colares com as cores preferi-

8 RAMOS, A. O negro brasileiro. Rio de Janeiro: Graphia, 2001. p. 30. Original publicado em 1934.

9 RAMOS, 2001, p. 31.

${ }^{10}$ THOMPSON, 1995, p. 82.

${ }^{11}$ Nome que designa as mulheres que estão em processo de iniciação nos candomblés.

12 PORTO, L. O ensino de história e cultura afro-brasileiras e a temática religiosa: dilemas enfrentados na aplicação da lei n. 10639/03. In: SILVA, P. V. B.; SILVA, J. G.; MACHADO, S. M. (Orgs.). Curso de especialização em educação das relações étnico-raciais. Curitiba: UFPR, 2017. p. 224-281. 
das das divindades a que pertencem; todas elas estão ligadas ao rito selvagem por mistérios que as obrigam a gastar a vida em festejos, a sentir o santo e a respeitar o pai-de-santo ${ }^{13}$.

João do Rio responde ao seu contexto sócio-histórico, que resultaram numa série de artigos que não contemporizam nem cientificam suas observações sobre pessoas reais. Vincularam mulheres que estão em processo de iniciação religiosa nos candomblés de maneira generalizante com a degradação moral, a degradação física, a desonestidade. Sendo essas mulheres a base do culto africano, não passavam, na visão do autor, de demoníacas, farsistas. ${ }^{14} \mathrm{O}$ feitiço e o medo do feitiço estabeleceram uma série de estudos e pesquisas, sendo que alguns pesquisadores salientam que um dos motivos de tamanha perseguição estaria associado a esse fato. Apresenta-se ao longo da história desses estudos, nas mais variadas vertentes, essa relação de medo e de condescendência. Quem primeiro utiliza o termo "condescendência" é Nina Rodrigues, em $O$ Animismo fetichista dos negros baianos ${ }^{15}$, para ilustrar que a crença no feitiço não era exclusividade dos negros, mas que os senhores e depois a elite, em várias situações, recorreriam às mandingas ${ }^{16} \mathrm{e}$ a rezas dos terreiros.

A associação de feitiço e feiticeiros à população negra já estava presente nos textos de João do Rio, que afirmavam que o feitiço era o nosso vício, nosso gozo e degeneração, mas que a alta sociedade carioca dos bairros de Botafogo e da Tijuca estava visitando as sessões. ${ }^{17}$ No Brasil, "medo do feitiço"18 estabelece o lugar das religiões afro-brasileiras na sociedade brasileira dando-se certa prevalência ao temor e à naturalização ${ }^{19}$ social e histórica, primeiro ao feitiço, segundo a quem realiza a feitiçaria, e terceiro a quem se deve combater.

\section{O medo do feitiço}

A respeito do feitiço, os trabalhos históricos remetem-se ao século XVIII do período colonial brasileiro e a devassas eclesiásticas sucedidas nas regiões das Minas entre 1721 e o princípio do século XIX, em que negros, em sua maior parte, "traziam na cor da pele a presença de um mundo secreto e desconhecido, de que a feitiçaria era um dos ecos ameaçadores" ${ }^{\prime 20}$. Cabe salientar a esse respeito os registros das representações oficiais do catolicismo sobre feitiçaria e seu temor. De certa forma

\footnotetext{
${ }^{13}$ RIO, J. As religiões do Rio. Rio de Janeiro: José Olympio, 1906. p. 35-36.

14 RIO, 1906, p. 13.

15 RODRIGUES, 2006, p. 108.

16 Ao longo da nossa história, o termo mandinga foi alterando e deturpando-se até ser conhecido nos diais atuais como magia, coisa feita, despacho. A origem do termo faz referência ao grupo étnico dos mandingos ou mandinka, grupo étnico da África Ocidental em que seus descendentes são do antigo Império do Mali. No Brasil eram praticantes do islamismo e considerados como tendo uma forte índole guerreira (RAMOS, 2001, p. 69).

17 RIO, 1906, p. 60-61.

18 MAGGIE, Y. O medo do feitiço - verdades e mentiras sobre a repressão às religiões mediúnicas. Religião e Sociedade, v. 13, n. 1, p. 72, 1986.

19 THOMPSON, 1995, p. 88.

20 SOUZA, M. L. Os desclassificados do ouro. Rio de Janeiro: Graal, 1986. p. 189.
} 
consolidaram intrinsecamente o Outro como ameaçador e vinculado ao "mal", e com isso estabeleceram uma distinção entre as práticas religiosas dos não brancos como desqualificadas e identificadas com a feitiçaria, ou seja, num cenário de práticas semelhantes, mas realizadas por brancos, a avaliação e a condenação tinham tratamento diferenciado. ${ }^{21}$ Em $A$ Cor do Feitiço, Mario Teixeira de Sá Junior elaborou um estudo sobre as práticas mágicas e a feitiçaria no Mato Grosso setecentista. ${ }^{22}$

Mario Teixeira de Sá reforça que a magia e a feitiçaria estiveram presentes desde a colonização portuguesa e seu controle foi também permanente. O órgão que sistematizou e perseguiu essas práticas foi a Inquisição ${ }^{23}$, que se fez presente no Brasil por meio das Visitas do Tribunal do Santo Ofício e das Visitas Diocesanas Eclesiásticas desde o ano de $1579 .{ }^{24} \mathrm{O}$ pesquisador analisa a documentação da Devassa Visita Geral da Comarca Eclesiástica de Cuiabá em 1785, cujo objetivo era averiguar as práticas desviantes dos africanos e de seus descendentes, que, nesse período, já estavam sob a égide de uma legislação municipal de 1753 , que no seu artigo $5^{\circ}$ buscou controlar os batuques dos negros, conforme as Posturas Municipais de Vila Bela na citação abaixo:

Por evitar inquietações que fazem aos ouvidos dos moradores da Vila [Bela], em que regularmente há doentes aos quais se fazem insuportáveis os batuques dos negros de noite, e não querendo todavia que eles deixem de ter essa diversão por pequeno alívio de seu trabalho e cativeiro: acordaram que os senhores dos escravos lhes não consintam batuque, por mais horas que até as de recolher, que são às nove da noite, porque também não é conveniente que eles nesse folguedo levem toda a noite estafando-se e sucedendo como se tem visto nesta Vila amanhecerem neste vício, ou fadário, e o senhor que consentir por mais das horas taxadas, será condenado em 6 oitavas para a Câmara pela primeira vez e pela segunda em dobro, e sendo caso que o senhor não presencie por estar ausente, sejam logo presos os que constarem armaram o batuque e na falta de averiguação destes, alguns dos que assistiram a ele, e com três dias de cadeia levarão quarenta açoites no pelourinho ${ }^{25}$.

A citação ilustra o universo de proibições que decorrerão no Brasil nos séculos seguintes em relação a atividades que envolvem manifestações de origem afro. O batuque e sua consequente proibição a que a citação se refere estavam de fato associados às práticas mágicas e às feitiçarias. Outro dado importante que Sá Junior relata na pesquisa do período setecentista na região mato-grossense foi que os espaços de ma-

${ }^{21}$ PORTO, 2017, p. 192.

${ }^{22}$ SÁ JUNIOR, M. T. A cor do feitiço: práticas e praticantes de magia e feitiçaria no Mato Grosso setecentista. Revista Brasileira de História das Religiões, v. 2, n. 6, p. 130-174, 2010.

${ }^{23}$ Segundo Novinsky (1987 apud SÁ JUNIOR, 2010, p. 130) “O Tribunal do santo Ofício da Inquisição, em Portugal, foi introduzido exclusivamente para fiscalizar e punir o descendentes de judeus que haviam sido convertidos à força ao catolicismo, e sob suspeita de praticar a religião judaica. Foi gradativa a ampliação de seus objetivos até abarcar diversos tipos de comportamento e crenças. Às heresias em matéria de fé juntaram-se feitiçarias, bruxarias, sodomia, bigamia, blasfêmias, proposições, desacatos e problemas diversos de sexualidade".

${ }^{24}$ SÁ JUNIOR, 2010, p. 130.

${ }^{25}$ ROSA; JESUS, 2002 apud SÁ JUNIOR, 2010. 
nifestações dessas crenças eram compartilhados por europeus, africanos e indígenas. ${ }^{26}$ A distinção entre práticas mágicas e práticas de "feitiçarias" iria acontecer 56 anos depois do primeiro registro de Bruno Pina em $1785^{27}$ - essa visita selaria uma conotação histórica do que se poderia distinguir o "O medo do feitiço" e a "Cor do feitiço".

O debate trazido pelo autor de $A$ cor do feitiço serve-nos como elemento descritivo não somente de uma época, mas de um cenário constitutivo que encontramos em João do Rio (1906), Nina Rodrigues (1900) e Arthur Ramos (1934). Esses responderam a um universo imaginário que associava feitiçaria não somente à cor de pele de um indivíduo, mas também às suas heranças culturais. $\mathrm{O}$ primeiro tem sua importância nesse texto pela repercussão da sua obra e ele é explícito no seu trabalho ao descrever num capítulo "rojando de medo diante do feitiço africano, do feitiço importado com os escravos [...] onde gorilas manhosos e uma súcia de pretas cínicas ou histéricas desencavam o futuro" 28 . O segundo, Nina Rodrigues, recebe uma análise maior, pela importância da sua obra pela importância e influência que ele exerce em muitos estudiosos das religiões de matriz afro-brasileira.

Nina Rodrigues é cânone e seu trabalho em $\mathrm{O}$ animismo Fetichista dos $\mathrm{Ne}$ gros baianos rendeu-lhe o discípulo Arthur Ramos e uma menção honrosa de um dos fundadores da Antropologia Moderna, o francês Marcel Mauss. A menção feita pelo antropólogo francês foi feita um ano após a obra ser publicada em língua francesa. Marcel Mauss escreveu uma pequena resenha sobre a "elegante monografia"29. Para os brasileiros, a obra também é importante porque ela estabeleceu um divisor no campo de estudo sobre a religiosidade brasileira e que de certa maneira influenciou a escrita de todos aqueles que trataram desse tema. A principal influência foi a distinção da religiosidade yorubá e banto; para Nina Rodrigues, os primeiros eram organizados e mais inteligentes que os Bantos, que segundo o pesquisador praticavam um fetichismo simples e rudimentar. ${ }^{30}$

Outra influência, e por que não um legado, foi consolidar o que já povoava o imaginário da sociedade brasileira: a associação de práticas de feitiçaria aos africanos e, consequentemente, aos seus descendentes. A própria credulidade que disseminou que o medo do feitiço como represália aos maus-tratos provocou receios e superstições na relação entre senhor e escravizados pode ser interpretada como uma dissimulação. ${ }^{31}$ Até porque essa credulidade não amenizou os maus-tratos, os açoites, os grilhões e o genocídio da população escravizada no Brasil. ${ }^{32} \mathrm{O}$ medo do feitiço e o negro como feiticeiro na descrição de Nina Rodrigues somente contribuíram no vínculo

${ }^{26}$ SÁ JUNIOR, 2010, p. 132-133.

27 “O primeiro registro da presença de um feiticeiro em Mato Grosso, até agora encontrado, é o de Manoel Francisco David, registrado no tribunal da santa Inquisição em 1729”' (SÁ JUNIOR, 2010, p. 133).

28 RIO, 1906, p. 50.

${ }^{29}$ RODRIGUES, 2006, p. 21.

30 RODRIGUES, 2006, p. 104.

31 THOMPSON, 1995, p. 83.

32 A esse respeito faço referência ao estudo de Luiz Mott (MOTT, Luiz. Terror na casa da torre: tortura de escravos na Bahia colonial. In: REIS, João José (Org.). Escravidão e invenção da liberdade: estudos sobre o negro no Brasil. São Paulo: Brasiliense, 1988). 
entre preconceito racial e religioso. É o que nos alerta o autor Porto ${ }^{33}$. Podemos comprovar ainda no trecho abaixo a deslegitimação da religiosidade da população negra:

Não é, portanto, por acaso que algumas das principais referências sobre os estudos do negro no Brasil produzidos no Final do século XIX e primeira metade do século XX o tenham sido por médicos (Nina Rodrigues, Arthur Ramos). O primeiro deles explicitamente adepto das teorias científicas racistas predominantes na época. As temáticas das diferenças evolutivas entre raças, da miscigenação, das possibilidades de instaurar o "progresso" no país fazem com que o negro se torne um problema e, ao mesmo tempo, um tema fundamental e legítimo de pesquisa no advento da república. E embora posteriormente as teorias racistas sejam explicitamente abandonadas, modelos classificatórios e de interpretação do contexto dos negros no Brasil construídos por Nina Rodrigues se mantêm como quadro interpretativo das manifestações de africanos e seus descendentes no país ${ }^{34}$.

A interpretação da autora revela para a nossa pesquisa que, do ponto vista da análise ideológica, temos no trabalho de Nina Rodrigues uma estratégia de construção simbólica que pode ser descrita como o expurgo do outro, que consiste na construção simbólica de um inimigo. ${ }^{35}$ Ao deslegitimar a religiosidade negra, que tem na sua essência a magia e o uso e conhecimento de forças sobrenaturais para intervenção neste mundo, não só percebe e invisibiliza "a importância do negro para a constituição da religiosidade brasileira, pois entre nós religião e cura sempre estiveram vinculadas"36, mas também denota essas práticas religiosas vinculadas a superstições e, voltando à matriz de difusão das formas racistas de compreender as religiões afro-brasileiras representadas por Nina Rodrigues (1900), descreve todos os que procuram esses "feiticeiros" nos terreiros de candomblés, à procura de folhas do mato, como "ignorantes" e "boçais", com exceção de alguns "espíritos superiores e esclarecidos" que não participam das crenças africanas:

O número em que ellas avultam ali sobre a mesa fatídica da feiticeira, bem indica a riqueza da clientela e a extensão da crença nas virtudes do feitiço. Mas esta clientela não se recruta sempre nas negras boçaes e ignorantes, sinão mesmo na melhor sociedade da terra. Para levantar as suspeitas que possam recair sobre as damas de qualidade que a queiram consultar, a mãe do terreiro fez instalar na sala principal da casa, bem em evidência, uma loja de modista. E que não é de todo falso o boato que insistência correu aqui há tempos, de que alguém não se resolvera a aceitar a presidência da província e mais tarde a pasta de ministro, sem prévia audiência de uma cartomante mãe de terreiro, prova a offerta que Isabel me faz, dos préstimos dos seus fetiches para o caso de eu pretender ser senador ${ }^{37}$.

\footnotetext{
${ }^{33}$ PORTO, 2017, p. 234.

${ }^{34}$ PORTO, 2017, p. 235.

35 THOMPSON, 1995, p. 87.

${ }^{36}$ PORTO, 2017, p. 197.

${ }^{37}$ RODRIGUES, 2006, p. 65.
} 
O etnocentrismo de Nina Rodrigues não o impediu de realizar um levantamento das populações escravizadas trazidas para o Brasil e o estudo das sobrevivências linguísticas desses grupos. Também não impediu a visão pessimista da possibilidade de civilização da população negra brasileira. A leitura e a compreensão dos textos de Nina Rodrigues permitem, entre outras leituras, entender que a distinção que ele realiza entre os negros mais "adiantados" presentes no Brasil e os mais "atrasados" é devido ao fato de os primeiros terem tido contato com os brancos e serem como ramos desses. ${ }^{38}$ As religiões de matriz afro-brasileira são religiões mágicas. O uso de forças sobrenaturais são preceitos incondicionáveis à sua prática ritualística. Essa compreensão é importante, pois ajuda a confrontar as acusações históricas de associação de feitiçarias, de marginalidade e de diabólica. Associam-se a isso as perseguições, repressões e todo um universo de preconceito racial e religioso no ambiente societário brasileiro. Acrescenta-se a isso o Decreto de 11 de outubro de 1890, que estabeleceu no seu Código a institucionalização da repressão, principalmente nos seus artigos 156,157 e $158 .{ }^{39}$

Por isso que a luta antirracista, por meio de uma ruptura dessa continuidade, deve confrontar essas teorias legitimadas pela tradição eterna e aceitável desse legado. Por isso que os componentes que envolvem o tema deste estudo envolvem uma releitura estratégica de diferentes áreas do conhecimento humano, como destaca Nilma Lino Gomes:

$\mathrm{O}$ racismo imprime marcas negativas em todas as pessoas, de qualquer pertencimento étnico-racial, e é muito mais duro com aqueles que são suas vítimas diretas. Abala os processos identitários. Por isso a reação antirracista precisa ser incisiva. Para se contrapor ao racismo faz-se necessária a construção de estratégias, práticas, movimen-

38 LEITE, D. M. O caráter nacional brasileiro: história de uma ideologia. 7. ed. São Paulo: UNESP, 2007.

${ }^{39}$ Citou-se em nota e na íntegra o Decreto $n^{\circ} 847$, de 11 de outubro de 1890 . Isso porque, segundo Maggie (1986, p. 74), até o final do século XX, os artigos estavam em vigor, com pequenas modificações. Veja o que estabelecem os artigos:

Art. 156. Exercer a medicina em qualquer dos seus ramos, a arte dentaria ou a pharmacia; praticar a homeopathia, a dosimetria, o hypnotismo ou magnetismo animal, sem estar habilitado segundo as leis e regulamentos: Penas - de prisão cellular por um a seis mezes e multa de $100 \$$ a $500 \$ 000$. Paragrapho unico. Pelos abusos commettidos no exercicio ilegal da medicina em geral, os seus autores soffrerão, além das penas estabelecidas, as que forem impostas aos crimes a que derem causa.

Art. 157. Praticar o espiritismo, a magia e seus sortilegios, usar de talismans e cartomancias para despertar sentimentos de odio ou amor, inculcar cura de molestias curaveis ou incuraveis, emfim, para fascinar e subjugar a credulidade publica: Penas - de prisão cellular por um a seis mezes e multa de $100 \$$ a $500 \$ 000$. $\S 1^{\circ} \mathrm{Si}$ por influencia, ou em consequencia de qualquer destes meios, resultar ao paciente privação, ou alteração temporaria ou permanente, das faculdades psychicas:

Penas - de prisão cellular por um a seis annos e multa de $200 \$$ a $500 \$ 000$.

$\S 2^{\circ}$ Em igual pena, e mais na de privação do exercicio da profissão por tempo igual ao da condemnação, incorrerá o medico que directamente praticar qualquer dos actos acima referidos, ou assumir a responsabilidade delles.

Art. 158. Ministrar, ou simplesmente prescrever, como meio curativo para uso interno ou externo, e sob qualquer fórma preparada, substancia de qualquer dos reinos da natureza, fazendo, ou exercendo assim, o officio do denominado curandeiro: Penas - de prisão cellular por um a seis mezes e multa de $100 \$$ a 500\$000. (CÂMARA DOS DEPUTADOS. Decreto $n^{\circ} 847$, de 11 de outubro de 1890. Brasília: Câmara dos Deputados, 1890. Disponível em: <http://www.planalto.gov.br/ccivil_03/decreto/1851-1899/d847. htm>. Acesso em: 24 fev. 2020). 
tos e políticas antirracistas concretas. É importante, também, uma releitura histórica, sociológica, antropológica e pedagógica que compreenda, valorize e reconheça a humanidade, o potencial emancipatório e contestador do povo negro no Brasil e a nossa ascendência africana ${ }^{40}$.

Entre os componentes que merecem a releitura que a autora cita no trecho acima está o fato histórico de as religiões de matriz africana serem vistas como um conjunto de estereotipia que não se resume somente em serem classificadas como religiões do "baixo espiritismo". Durante as quatro primeiras décadas do século XX, foram desqualificadas e relacionadas a diferentes delitos, entre eles os de atentado à "moral" e aos "bons costumes", "algazarra". Tudo isso se enquadrava na repressão e numa série de campanhas que os jornais faziam e, é claro, no Código Penal vigente até 1940. ${ }^{41}$ Entre as acusações predominavam o curandeirismo e a magia negra.

Além dessas acusações, também se concretizou uma série de categorias acusatórias que certamente marcam a vivência de qualquer indivíduo pós-república velha brasileira, expressões que deixaram um legado na estrutura sociorracial da nossa história, termos que se constituíram como conceitos definidores de uma forma de ritual ou crença. ${ }^{42}$ Eles, entretanto, foram além, pois esses conceitos também marcam um grupo étnico na transição que esses precisam "superar" para chegar a um estágio mais elevado de "civilidade". Até mesmo porque os acusados são sempre os mesmos, o que varia são os acusadores. Conforme Maggie salienta:

Resolvi listar essas categorias e expressão e acusatórias recorrentes nos discursos da imprensa, da polícia, da justiça, dos membros desses terreiros e nas formulações dos intelectuais: essa nódoa negra; essa falta de civilidade; esse erotismo desenfreado; esse foco de devassidão e loucura (onde ogans licenciosos, lassos mas nunca fartos, procuram saciar seus desejos); esses locais de excessos e orgias, de crime, de ignorância, onde selvagens incomodam o sossego público; esses antipatriotas; essa tradição africana que deve ser extirpada; essa ocasião para a devassidão; esses charlatões que exploram a credulidade pública e o exercício ilegal da medicina; essas práticas bárbaras que deprimem nossos costumes e envergonham nossa civilização; esses curandeiros, charlatões involuntários; esses usuários de maconha; esses portadores de imagens impuras de loucura criminosa; esses exploradores desavergonhados da credulidade pública das classes baixas; pessoas de tendências morais afrouxadas, desse o estupro ao assassinato; essa cesta de lixo; esse baixo ou falso espiritismo; essas deturpações; degenerações, falsificações; a magia negra; essas mistificações; essa charlatanice ${ }^{43}$.

A lista de categorias definidoras salientada por Maggie ${ }^{44}$ molda um quadro de representação discursiva e se torna ideológica segundo interpretação deste estudo

40 GOMES, N. L. Apresentação. In: . Negritude: usos e sentidos/kabengele munanga. Belo Horizonte: Autêntica, 2009. p. 9.

41 MAGGIE, 1986, p. 72-74.

42 MAGGIE, 1986, p. 79.

${ }^{43}$ MAGGIE, 1986, p. 79.

44 MAGGIE, 1986. 
por essa representar o modus operandi que podemos identificar como diferenciação, cuja ênfase se estabelece na distinção, na diferença e nas divisões, ou seja, por mais que seja próximo e muitas vezes sofra as mesmas agressões, perseguições e repressões que outro, um vai tentar diferenciar-se desse quadro. ${ }^{45}$ Talvez isso ajude a compreender o que alguns intelectuais e lideranças religiosas, já na década de 1930, encabeçaram com o processo de legitimação e proteção dos terreiros "autênticos" dos terreiros "falsos", a justificava dos primeiros era protegê-los da perseguição policial e da repressão. ${ }^{46,47}$

Também está presente nesse mesmo discurso a ideia cujo objetivo era fortalecer uma retórica identitária em que o candomblé de Nagô se oporia ao candomblé de $\mathrm{Caboclo}^{48}$ e com isso estabelecendo uma dicotomia entre pureza e mistura; "religião" e "magia"; hierarquia e desordem; harmonia e dissenção. ${ }^{49}$ A perspectiva de fortalecer os terreiros "puros" em detrimento dos terreiros "misturados", sendo os segundos como aqueles que praticam "a feitiçaria, o charlatanismo", logo sujeitos à repressão e à ação do Estado, ao contrário dos primeiros que teriam que ter o reconhecimento de religião. ${ }^{50}$ Assim como ressalta Beatriz Góis Dantas sobre o empenho e a participação de intelectuais na proteção dos terreiros "tradicionais":

Aqui a luta contra a repressão policial e a luta contra a perda das tradições africanas aparecem juntas. Ambas se fazem com a participação dos intelectuais que, tendo feito sobre os cultos um recorte em que a fidelidade à África é ponto de referência, vão terminar interferindo nas linhas seguidas pela repressão. Os terreiros mais "tradicionais", objeto de estudos dos antropólogos, centros de "verdadeira religião" aos quais eles emprestavam sua proteção, conseguiam ficar a salvo da repressão policial que incidia mais violentamente sobre os "impuros", não valorizados. ${ }^{51}$

Entre esses intelectuais estava Roger Bastide com o seu livro As religiões Africanas no Brasil de 1960, em que descreve: "A desagregação urbana antecedeu a desagregação rural. Enquanto candomblé, todavia existente do século XX, se transforma-

45 THOMPSON, 1995, p. 87.

46 MAGGIE, 1986, p. 77.

47 Talvez isso explique que o primeiro grande movimento contra a intolerância religiosa tenha se iniciado em 2000 com a participação de várias entidades civis e religiosas quando o fenômeno de perseguição e repressão já era exercido e movido por outro fenômeno social, os neopentecostais (SILVA, V. G. Prefácio ou notícias de uma guerra nada particular - os ataques neopentecostais às religiões afro-brasileiras e aos símbolos da herança africana no Brasil. In: Intolerância religiosa: impactos do neopentecostalismo no campo religioso afro-brasileiro. São Paulo: Universidade de São Paulo, 2007. p. 22).

48 "O candomblé de caboclo é uma modalidade do angola centrado no culto exclusivo dos antepassados indígenas. Foi provavelmente o candomblé angola e o de caboclo que deram origem à umbanda" (PRANDI, R. As religiões negras do Brasil: para uma sociologia dos cultos afro-brasileiros. Revista USO, São Paulo, v. 28 , p. 66, 1996).

49 FRY, P. As religiões africanas fora da África: o caso do Brasil. Rio de Janeiro: Museu Nacional-PPGAS, 1984. (mimeo). p. 37-45.

50 DANTAS, B. G. Repensando a pureza nagô. Religião e sociedade, n. 8, p. 135-146, jul. 1982. p. 140.

51 DANTAS, 1982, p. 140-141. 
va em macumba na capital" "52. Macumba no Rio não tem caráter religioso, desnatura no espetáculo cujo fim é o prolongamento em pura "magia negra" 53 . Em outro centro urbano e industrial, a desagregação do ritual africano é pior, caso de São Paulo, que Bastide identifica como sendo um culto individualizado que "passou da forma coletiva para a forma individual, ao mesmo tempo se degradando de religião em magia. $\mathrm{O}$ macumbeiro, isolado, sinistro temido como formidável feiticeiro" ${ }^{4}$.

Bastide alega que no candomblé "puro" permanece o controle social, um instrumento de solidariedade e de comunhão; ao contrário da macumba, que além de sofrer uma mistura étnica com a entrada de brancos, origina-se da "classe proletária nascente" 55 . Isso resultou num parasitismo social, numa exploração desavergonhada da credulidade das classes baixas e no seu afrouxamento das tendências imorais, desde o estupro, até frequentemente o assassinato. ${ }^{56,57}$ A postura de Bastide é de certa forma sectária em relação à desagregação do candomblé "puro" e a uma reminiscência de um candomblé como espaço de sociabilidade dos negros, onde esses podiam se reunir, celebrar seus cultos, enterrar seus mortos e prestar ajuda uns aos outros. Entendem-se essa leitura e análise que o estudioso realizou em torno das manifestações religiosas de raízes do candomblé tradicionais, nascentes aquela época.

Aliada a isso, cabe ainda uma ressalva importante sobre os diferentes temas que Roger Bastide aborda em sua obra. Cremos que seja uma linha mestra e que possibilita uma compreensão histórica do pensamento do autor, que entendeu que o culto dos orixás em terras brasileiras respondeu diretamente à condição desumana, à fragmentação e à segmentação das famílias, indivíduos que poderiam se transformar num desafio real aos grupos dominantes. ${ }^{58}$ Trazidos na condição de escravizados e mesmo numa condição de trabalho compulsório e de imposição de novas crenças, os diferentes grupos étnicos e de diferentes tradições religiosas conseguiram constituir uma alteridade religiosa. Mesmo com as transformações que o autor salienta, entre

52 BASTIDE, 1960, p. 401.

53 BASTIDE, 1960, p. 411.

54 BASTIDE, 1960, p. 412.

55 BASTIDE, 1960, p. 407.

56 BASTIDE, 1960, p. 414.

${ }^{57}$ Creio que cabe nesse trecho do capítulo uma ressalva em torno de noticiários que associam e que muitas vezes aparecem em jornais sobre sacrifícios humanos, sequestro de crianças relacionados à "magia negra" e a relação disso com religiões que têm sua origem ou influência nas religiões afro-brasileiras. Aproprio-me de uma consideração que Silva (2007) realiza em torno dessa questão. Lembrando que o autor não está fazendo nenhum contraponto a Roger Bastide, mas creio que as considerações desse pesquisador cabem logo nesse ponto tendo em vista que iremos analisar em seguida questões relacionadas às interpretações e representações em torno do que se classifica e se identifica no senso comum e no cotidiano das pessoas, o termo macumba. O autor esclarece: "É importante lembrar que sacrifício humano obviamente não faz parte dos ritos aceitos pelas religiões afro-brasileiras, o que não impede, entretanto, que em alguns casos, conforme notícias da imprensa (O Estado de S. Paulo, 22/06/1999 e O Dia, 17/08/2000; 21/09/2000; 02/02/2000) os autores desse tipo de crime se identifiquem como adeptos dessas religiões. Nesses casos, enfatizo que não é a prática religiosa que determina o crime (ainda que esse se apresente com certas características dos ritos sacrificiais das religiões afro-brasileiras), mas o criminoso, que, sob uma óptica particular, extrai do sistema religioso justificativa para o crime" (SILVA, 2007, p. 13).

58 THOMPSON, 1995, p. 87. 
candomblé rural, macumba rural, macumba urbana e o espiritismo de umbanda, nessa fusão que consequentemente resultou em novas funções, cabe entender o que se tornou a cultura de contraste dos grupos interétnicos, sustentar sua ancestralidade entre as vertentes familiar e religiosa em relação ao culto dos orixás.

\section{O papel das religiões cristãs neopentecostais no reforço ao preconceito racial e nas atuações dos narcopentecostais}

Entre os diferentes questionamentos e hipóteses em torno da escolha desse subtítulo e do recorte nessa corrente religiosa está no fato dos neopentecostais terem encontrado um filling mercadológico (esse termo tem aqui um sentido de estratégia na preferência de determinado público e de um ajuste na concorrência). Em que consiste esse filling? A intolerância e o reforço ao preconceito racial e religioso com relação às religiões de matriz afro-brasileira possibilitaram às correntes neopentecostais e em específico aumentar o número de fiéis por meio da conversão de adeptos das outras religiões rivais. Isso ocorre na tentativa de "dizimar a concorrência espírita nos estratos populares com o fechamento de centros espíritas, tendas de umbanda e terreiros de candomblé, sobretudo, nas redondezas dos templos evangélicos" 59 . Outrora tais segmentos religiosos exerciam essas ações por meio e com investimento num aparato midiático que incluía programa de rádio, sites na Internet e diversos materiais de divulgação religiosa (livros, jornais, revistas e folhetos), programas religiosos como "Fala que eu te escuto"; "Ponto de luz"; "Pare de sofrer"; "Show da Fé"60. Também um investimento na representação política, e existe uma frente parlamentar que no Legislativo de 2019 soma 91 congressistas. Se a bancada fosse um partido, esse seria o maior na Câmara Federal. Sua ação na câmara tem sido de defesa dos valores conservadores da família e da tradição, conhecida com a bancada do boi, da bala e da Bíblia, tendo atuado para contrapor as demandas de movimentos sociais na Comissão de Direitos Humanos e, em 2014, atuado na discussão do relatório do Plano Nacional de Educação (PL 1085/2010), especialmente atacando o que seria uma "ideologia de gênero" do texto, com foco em especial nas proposições dos grupos LGBT, mas atacando a "agenda da diversidade" em seu conjunto.

Ainda sobre o papel e a força que o segmento neopentecostal exerce no contexto sócio-histórico brasileiro, temos nos defrontado com um fenômeno paradoxal que vem se alastrando nos últimos três anos com um fenômeno paradoxal dos traficantes evangélicos nas favelas do Rio de Janeiro, denominados como "narcopentencostais". Facções têm agido em diferentes regiões da Baixada Fluminense. A devoção deturpada desses neopentecostais tem se refletido em intolerância, intimidações e perseguições. Representantes do Tribunal de Justiça, Ministério Público e a Comissão de Combate à Intolerância Religiosa contabilizaram 176 terreiros fechados após ataques de traficantes no ano de 2019; o silêncio e o medo predominam, o que ocasiona baixo

\footnotetext{
59 MARIANO, R. Pentecostais em ação: a demonização dos afro-brasileiros. In: SILVA, 2007, p. 337.

${ }^{60}$ SILVA, 2007, p. 11.
} 
número de denúncias junto a essa comissão - no ano passado essa comissão não recebeu nem cem denúncias.

Entre os diferentes relatos que Silva revela de intimidações e perseguições, há inclusive, em locais tradicionais como Casa Branca e o Gantois no bairro Engenho Velho, a utilização de carro de som em frente a um terreiro na cidade Tirantes em São Paulo; panfletagem contra os cultos e atividades religiosas públicas em ataques a símbolos que representam as religiões afro-brasileiras. ${ }^{61}$ No que tange à violação de direitos no que se refere à manifestação de fé e de religiosidade num espaço público, um grupo quer consolidar o evangelismo independente de que o outro aceite ou não essa conversão. Essa situação revela um fenômeno que não está somente no debate sociopolítico do respeito às diferenças, do combate à intolerância religiosa. O evangelismo neopentecostal não reconhece, da mesma forma que outras igrejas cristãs históricas em certos momentos da história também não reconheceram, a laicidade.

\section{Considerações finais}

Os discursos das religiões de matrizes judaico-cristãs têm no anúncio apologético a posição detentora da única e irrecusável verdade, o que de certa forma tem, ao longo dos séculos, dificultado o diálogo teológico, doutrinal, cultural, educacional com as outras expressões religiosas de matriz afro-brasileira. A relação assimétrica entre as matrizes estabelece-se entre o branco europeu, cristão e colonizador e o negro afro-brasileiro, "pagão" e escravizado, em que a ocultação e negação tornavam-no um outro que não era ele mesmo. ${ }^{62}$

É esse o horizonte no qual se deu a relação assimétrica entre o branco europeu, cristão e colonizador e o negro africano, "pagão" e escravizado. Nessa relação não houve encontro, não houve diálogo, porque não havia um outro, mas apenas um estranho e diferente, que, a despeito de seus gritos, clamores e resistência, deveria se tornar familiar e conhecido, por meio de um processo de assimilação catequética, cuja realização se dava no momento em que esse estranho e diferente tornava-se um outro que não era mais ele mesmo. ${ }^{63}$

Uma das características mais frequentes é a presença do branco como representante natural da espécie, a "branquidade normativa", que expressa a estratégia ideológica de naturalização; umas das estratégias do modo de operação da reificação, muitas vezes, é utilizada nas formas de representação em imagens de personagens bíblicos (tipos físicos árabes e negros) com padrões europeus brancos e, muitas vezes, traços nórdicos (além de tonalidade de pele, também cabelos e olhos claros). ${ }^{64}$ Também é evidenciado como desafio quando professores precisam abordar as heran-

\footnotetext{
61 SILVA, 2007, p. 13.

${ }^{62}$ GOIS, Aurino José. O Diálogo inter-religioso entre o cristianismo e as tradições afro-brasileiras. In: AMÂNCIO, Íris Maria da costa (Org.). África-Brasil-África: matrizes heranças e diálogos contemporâneos. Belo Horizonte: Nandyala, 2008. p. 86.

${ }^{63}$ GOIS, 2008, p. 86.

${ }^{64}$ THOMPSON, 1995 , p. 87-88.
} 
ças religiosas africanas no Brasil. Embora esse não seja um problema novo, somente agora toma uma dimensão mais aguda em razão da inserção do artigo 26A na LDB pelas Leis Federais 10.639/03 e 11.645/08, que determinam o ensino de História e Cultura Africana, Afro-Brasileira e Indígena.

As transformações e interpretações salientes no artigo revelam entre as religiões de matrizes africanas diferentes vieses entre eles: candomblé rural, macumba rural, macumba urbana e o espiritismo de umbanda, nessa fusão que consequentemente resultou em novas funções, cabe entender o que se tornou a cultura de contraste dos grupos interétnicos, sustentar sua ancestralidade entre as vertentes familiar e religiosa em relação ao culto dos orixás. É esse o horizonte no qual se deu a relação assimétrica entre o branco europeu, cristão e colonizador, e o negro africano, "pagão" e escravizado. Nessa relação não houve encontro, não houve diálogo, porque não havia um outro, mas apenas um estranho e diferente que, a despeito de seus gritos, clamores e resistência, deveria se tornar familiar e conhecido por meio de um processo de assimilação catequética, cuja realização se dava no momento em que esse estranho e diferente tornava-se um outro que não era mais ele mesmo. No entanto, após mais de três séculos de tentativa de eliminação dos códigos religiosos africanos existentes em nosso país, perduram terreiros de candomblé, terecô, umbanda, batuque, tambor de mina espalhados em diversas regiões do Brasil. Foram nesses espaços que a cosmogonia das religiões de matriz afro-brasileira, enquanto pilares de ancestralidade (Bantos) e ritualidades africanas, e que os Orixás (Yorubá), Inquinces, Angola, Fon, Yorubá, Voduns, Eguns e caboclos tornaram-se símbolos da cosmogonia africana revivida e revitalizada pela natureza e pela crença de sua ação sobre o mundo na vida daqueles que acreditam.

\section{Referências}

BASTIDE, R. As religiões africanas no Brasil: contribuições a uma sociologia das interpenetrações de civilizações. São Paulo: Universidade de São Paulo, 1960.

CÂMARA DOS DEPUTADOS. Decreto $n^{\circ} 847$, de 11 de Outubro de 1890. Brasília: Câmara dos Deputados, 1890. Disponível em: <http://www.planalto.gov.br/ccivil_03/decreto/1851-1899/ d847.htm>. Acesso em: 24 fev. 2020.

DANTAS, B. G. Repensando a pureza nagô. Religião e sociedade, n. 8, p. 135-146, jul. 1982. FRY, P. As religiões africanas fora da África: o caso do Brasil. Rio de Janeiro: Museu Nacional-PPGAS, 1984. (mimeo).

GOIS, Aurino José. O Diálogo inter-religioso entre o cristianismo e as tradições afro-brasileiras. In: AMÂNCIO, Íris Maria da costa (Org.). África-Brasil-África: matrizes, heranças e diálogos contemporâneos. Belo Horizonte: Nandyala, 2008.

GOMES, N. L. Apresentação. In: . Negritude: usos e sentidos/kabengele munanga. Belo Horizonte: Autêntica, 2009. (Coleção Cultura Negra e Identidades).

LEITE, D. M. O caráter nacional brasileiro: história de uma ideologia. 7. ed. São Paulo: UNESP, 2007.

MAGGIE, Y. O medo do feitiço - verdades e mentiras sobre a repressão às religiões mediúnicas. Religião e Sociedade, v. 13, n. 1, p. 72-139, 1986.

MARIANO, R. Pentecostais em ação: a demonização dos afro-brasileiros. In: SILVA, V. G. (Org.). Intolerância religiosa: impactos do neopentecostalismo no campo religioso afro-brasileiro. São Paulo: Universidade de São Paulo, 2007. 
MOTT, L. Terror na casa da torre: tortura de escravos na Bahia colonial. In: REIS, João José (Org.). Escravidão e invenção da liberdade: estudos sobre o negro no Brasil. São Paulo: Brasiliense, 1988.

PORTO, L. O ensino de história e cultura afro-brasileiras e a temática religiosa: dilemas enfrentados na aplicação da lei n. 10639/03. In: SILVA, P. V. B.; SILVA, J. G.; MACHADO, S. M. (Orgs.). Curso de especialização em educação das relações étnico-raciais. Curitiba: UFPR, 2017. PRANDI, R. As religiões negras do Brasil: para uma sociologia dos cultos afro-brasileiros. Revista USO, São Paulo, v. 28, p. 64-83, 1996.

RAMOS, A. O negro brasileiro. Rio de Janeiro: Graphia, 2001. Original publicado em 1934. RIO, J. As religiões do Rio. Rio de Janeiro: José Olympio, 1906.

RODRIGUES, N. O animismo fetichista dos negros baianos. Rio de Janeiro: UFRJ; Biblioteca Nacional, 2006.

SÁ JUNIOR, M. T. A cor do feitiço. Práticas e praticantes de magia e feitiçaria no Mato Grosso setecentista. Revista Brasileira de História das Religiões, v. 2, n. 6, p. 130-174, 2010.

SILVA, V. G. Prefácio ou notícias de uma guerra nada particular - os ataques neopentecostais às religiões afro-brasileiras e aos símbolos da herança africana no Brasil. In: Intolerância religiosa: impactos do neopentecostalismo no campo religioso afro-brasileiro. São Paulo: Universidade de São Paulo, 2007.

SOUZA, M. L. Os desclassificados do ouro. Rio de Janeiro: Graal, 1986.

THOMPSON, J. B. Ideologia e cultura moderna: teoria social na era dos meios de comunicação de massa. Petrópolis: Vozes, 1995. 